\title{
SUSTAINABILITY ASSESSMENT OF ECOLOGICAL INTENSIFICATION PRACTICES IN COCONUT PRODUCTION
}

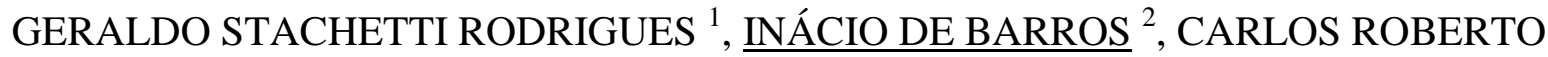 MARTINS $^{3}$}

\section{INTRODUCTION}

Currently, Brazil is the fourth largest producer of coconut in the world, with around 2.8 million tonnes harvested in about 287,000 ha (FAO, 2014). Although present in different regions of the country, more than $90 \%$ of the planted area occurs along the coast of the Northeast and part of the North. Coconut production is an important employment and income generating activity, contributing significantly to the development of the producing regions. Even if part of the harvest is typically extractive, coconut cultivation demands high technological levels to achieve adequate productivity, and high production costs have caused recurring crises in the industry, indicating the exhaustion of the conventional production model (MARTINS AND JESUS JUNIOR, 2014).

The costs associated with the necessary adoption of technologies to enable agriculture in general, and coconut production in particular, require that increases in production must come from higher levels of productivity, increasing efficiency by the intensification of cultivation practices (TILMAN et al., 2002). In the past agricultural intensification was characterized mainly as a result of breeding, associated with increases in the use of inputs such as chemical fertilizers, pesticides, irrigation and mechanization, a model that has shown adverse effects on the environment. Today, by contrast, 'agricultural ecological intensification' has been proposed, defined as the "maximization of primary production per unit area without compromising the system's ability to maintain its productive capacity" (FAO, 2009), or as "producing more food from the same area of land while reducing the environmental impacts" (ROYAL SOCIETY OF LONDON, 2009).

Thus, 'Ecologically Intensive Systems' (EIS) have been a central reference to promote diversification of agricultural activities, as well as for the development and adoption of integrated techniques and management practices aimed at producing food in line with the environmental conditions and the local availability of natural resources, focusing on economic

\footnotetext{
${ }^{1}$ Ph.D., Embrapa Meio Ambiente, e-mail: geraldo.stachetti@embrapa.br;

${ }^{2}$ Ph.D., Embrapa Tabuleiros Costeiros, e-mail: inacio.barros@embrapa.br;

${ }^{3}$ Dr., Embrapa Clima Temperado, e-mail: carlos.r.martins@embrapa.br;
} 
profitability, with parsimony in the use of external inputs and lower production costs. The purpose of this study is to analyze the environmental performance of coconut production in different technological contexts, as to identify the conditions and factors by which changes towards ecologically intensive practices have had greater potential to promote sustainability.

\section{MATERIAL AND METHODS}

A wide variety of methodological approaches have been developed to meet a growing international demand for sustainability indicators (SANCHEZ AND MATOS, 2012; OLDE et $a l .$, 2016.). In this research, we seek to identify the technological intensification contexts in which the highest environmental performance gains are observed in coconut production, favoring the recommendation of management practices that promote sustainability. For this purpose, the APOIA-NovoRural indicators system has been applied (RODRIGUES AND CAMPANHOLA, 2003) as an adequate environmental assessment tool, applicable onto the variety of production contexts and technology adoption levels observed, and considering the diversity of environments and local coconut production characteristics.

The APOIA-NovoRural system consists of 62 indicators grouped in five sustainability dimensions, namely: (i) Landscape ecology, (ii) Environmental quality (air, water and soil), (iii) Socio-cultural values, (iv) Economic values and (v) Management and administration. Organized into a set of multi-attribute weighting matrices (scale normalized from 0 to 1 , with baseline modeled in 0.7), the integrated indicators allow quantitative and objective analysis of environmental performance, in field inspections carried out with analytical instrumentation and management data obtained with the farmers (RODRIGUES et al., 2010).

For the current study, six reference rural establishments partners with Embrapa in technology development and transference programs were selected to carry out case studies. These reference farms showed different levels of intensification and diversification, varied technology adoption capacities, and entrepreneurial strategies from family businesses to large-scale enterprises. Field data surveys took place between July 2013 and November 2014, and results from each case study were reported back to the rural establishment managers in 'environmental management reports', containing all documentation on environmental conditions and recommendations towards sustainable production.

\section{RESULTS AND DISCUSSION}

The analysis of the six case studies pointed out the great influence of environmental conditions, particularly climate and soil fertility constraints, on the environmental performance of farms (Figure 1). Main recommendations included adjustments and 
66

parsimony in the application of fertilizers, as to avoid excesses that result in financial losses (case of phosphorus) and water contamination risks (case of nitrogen). Also, corrections and increase in the supply of organic matter, to correct natural deficiencies and improve nutrient and water retention capacity in the naturally very sandy soils.

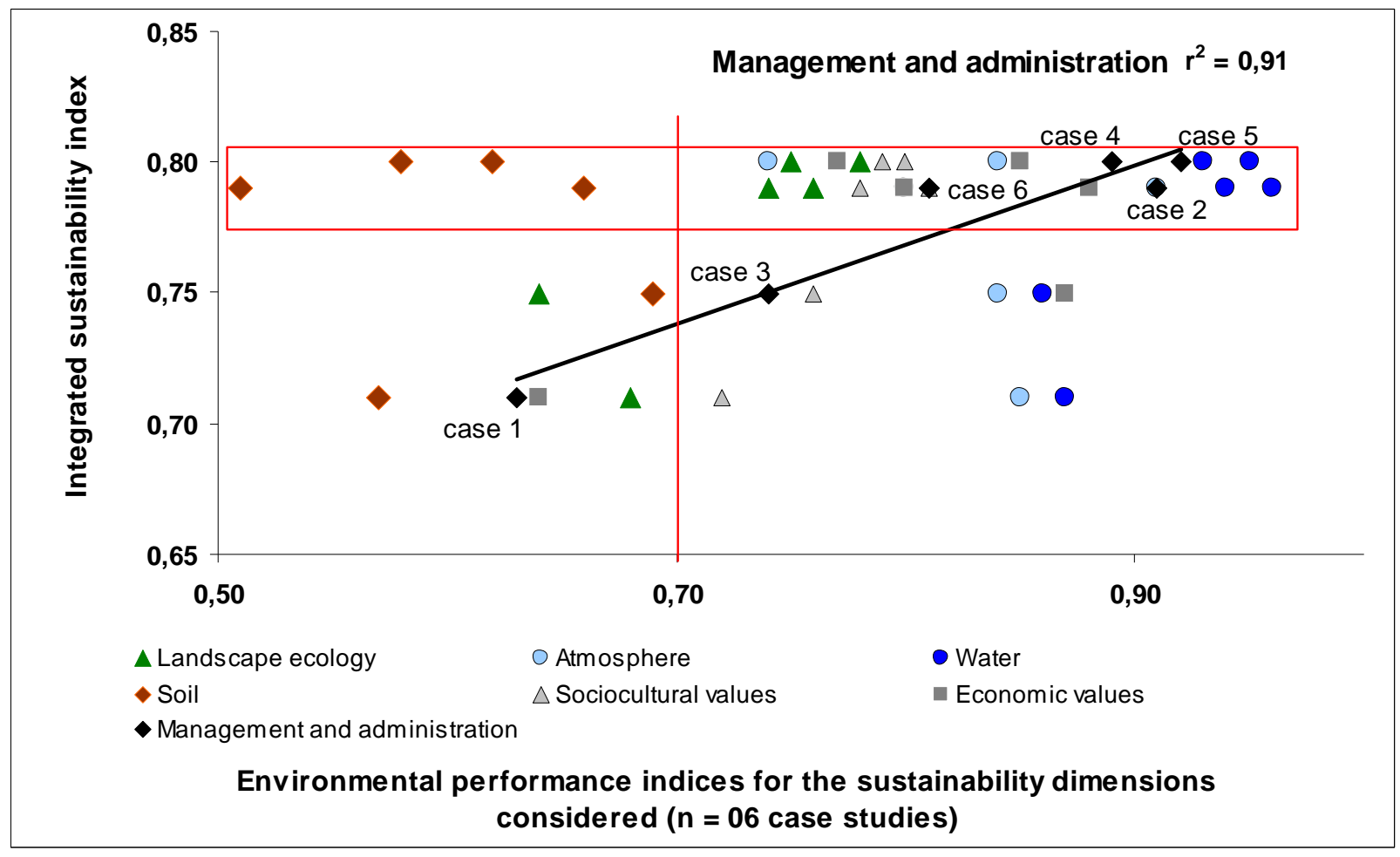

Figure 1 - Results of environmental indicator analyses in reference coconut production farms. The four rural establishments characterized as 'ecologically intensive' are highlighted (red frame), and cases studies are identified for the Management and administration dimension.

In general, the other indicators related to the Environmental quality dimensions were suitable in the studied farms, such as compliance with landscape management requirements, excellent water quality and lack of noticeable atmospheric emissions. The Economic values dimension proved to be generally quite adequate, although with a situation of negative performance due to particularly severe drought in recent years. Socio-cultural values indicators were rather favorable, given the provision of training to employees, very good employment and benefits conditions, and access to basic services. The Management and administration dimension proved to be closely dependent on the entrepreneurial and productive contexts of the studied establishments, both for those dedicated to coconut monocultures as well as the diversified ones. 
A close correlation was observed between the Management and administration dimension and the integrated sustainability indices (see trend line, highlighted in Figure 1). This result supports the hypothesis according to which the sustainability of rural activities in general, as well as for coconut production in particular, can be strongly favored by the adoption of environmental management tools, such as the APOIA-NovoRural system. By the same token, the environmental performance of the rural establishments dedicated to coconut production was much improved when the productive context was more diversified and integrated, attesting to the value of technology adoption and ecological intensification as strategies to improve sustainability.

\section{ACKNOWLEDGEMENTS}

We are thankful to the farm administrators who lent their knowledge and experience in favor of this study, Mrs. Fernanda Gruenewald, Mr. Roberto Shibata, Mr. Hildeberto B. dos Santos, Mr. Luciano S. Lima, Mrs. Rita L. M. Grangeiro, and Mr. Paulo Manoel P. Lins.

\section{REFERENCES}

FAO. Glossary on Organic Agriculture. FAO, Rome (ITA). 2009. 163 p.

FAO. World Production 2014. Available at: <www.faostat.org.br>. Access 20 jan. 2016.

MARTINS, C.R,; JESUS JÚNIOR, L. A. Produção e Comercialização de Coco no Brasil Frente ao Comércio Internacional: Panorama 2014. Documentos 184. Embrapa Tabuleiros Costeiros. Aracaju, SE. 51 p. 2014.

OLDE, E. M. D., OUDSHOORN, F. W., SORENSEN, C. A. G., BOKKERS, E. A. M., BOER, I. J. M. Assessing sustainability at farm-level: Lessons learned from a comparison of tools in practice. Ecological Indicators, v. 66, pp. 391-404. 2016.

RODRIGUES, G. S.; CAMPANHOLA, C. Sistema integrado de avaliação de impacto ambiental aplicado a atividades do novo rural. Pesquisa Agropecuária Brasileira, Brasília, v. 38, n. 4, p. 445-451, 2003.

RODRIGUES, G.S., RODRIGUES, I., BUSCHINELLI, C.C. DE A., DE BARROS, I. Integrated farm sustainability assessment for the environmental management of rural activities. Environmental Impact Assessment Review. v. 30, n. 4, p. 229-239, 2010.

ROYAL SOCIETY OF LONDON. Reaping the Benefits: Science and the Sustainable Intensification of Global Agriculture. Royal Society of London, London, UK. 73 pp. 2009.

SANCHEZ, G. F., MATOS, M. M. Marcos metodológicos para sistematização de indicadores de sustentabilidade da agricultura, [SYN]THESIS, Rio de Janeiro, v. 5, n. 2, p. 255-267, 2012.

TILMAN, D., CASSMAN, K.G., MATSON, P.A., NAYLOR, R., POLASKY, S. Agricultural sustainability and intensive production practices. Nature, v. 418. pp. 671-677. 2002. 